\title{
PENGEMBANGAN APLIKASI SISTEM E-TICKETING KONSER MUSIK DENGAN SEATING NUMBER PADA WEBSITE MOTIKDONG.COM
}

\author{
Wahyudi \\ Universitas Bina Sarana Informatika \\ Jl. Dewi Sartika Blok, J1. H. Abdul Hamid No.77, RT.8/RW.4, Cawang, Kramat Jati, Jakarta 13630 \\ Email : wahyudi.wau@bsi.ac.id
}

\begin{abstract}
Abstrak
E-Ticketing adalah suatu cara untuk mendokumentasikan proses penjualan online yang hasil keluarannya berupa tiket yang dapat memudahkan orang untuk membeli tiket untuk berbagai acara semua konser dari satu situs web. Tiket dapat dibeli online melalui pembayaran dengan metode transfer ataupun kartu kredit. Customer tidak perlu lagi menghabiskan waktu untuk datang ke lokasi penjualan tiket, mereka dapat langsung memesan tiket konser yang dijual dari mana saja dan kapan saja dengan kemudahan berbagai sarana pembayaran, serta tidak perlu khawatir akan hilangnya tiket, dicuri, tertinggal, atau bahkan tercebur air, bahkan E-ticketing memungkinkan anda, membelikan tiket untuk kerabat dan orang lain. Permasalahannya adalah customer masih perlu menukarkan tiket fisik dan memilih kursi yang akan mereka tempati pada saat menonton konser, sehingga mereka harus hadir lebih awal jika ingin mendapatkan kursi yang sesuai dengan keinginannya, karena jika hadir belakangan akan menyebabkan kursi yang akan dipilih sudah ditempati oleh orang lain. Dalam hal ini penulis akan mencoba mengembangkan sistem informasi penjualan tiket konser dengan metode seating number. Hasil penelitian ini diharapkan mampu mengatasi persoalan tersebut diatas, sehingga customer bisa langsung memilih kursi saat memesan tiket konser di website, sehingga tidak merepotkan customer pada saat penukaran tiket fisik pada hari-H. Dalam pengembangan sistem ini penulis menggunakan metode prototype yang didalamnya mencakup dari pengembangan sistem pada penelitian sebelumnya yang ditulis oleh Wahyudi, M.Kom. kemudian dikembangkan fitur seating number.
\end{abstract}

Kata Kunci : penjualan tiket, penjualan tiket konser, seating number, E-ticketing

\begin{abstract}
E-Ticketing is a way to document the online sales process that results in the form of tickets that can make it easier for people to buy tickets for events, all concerts from the website. Tickets can be purchased online through payment using the transfer method or credit card. Customers no longer need to spend time for coming to buy ticket on location, they can directly order concert tickets that are sold from anywhere and at any time with the ease of various means of payment, and do not have to worry about lost tickets, stolen, left behind, or even splashed with water. E-ticketing even allows you to buy tickets for relatives and others. The problem is that customers still need to exchange physical tickets and choose the seats they will occupy when watching a concert, so they have to be present early if they want to get the seats that they want, because if they are present later it will cause the selected seats to be occupied by others. In this case the author will try to develop a concert ticket sales information system with a seating number method. The results of this study are expected to be able to overcome the above problems, so that customers can immediately choose a seat when ordering concert tickets on the website, so it does not bother the customer when exchanging physical tickets on D-day. In developing this sistem the author uses the prototype method which includes the development of the sistem in previous research written by Wahyudi, M.Kom. then the seating number feature was developed.

Keyword: ticket sales, online concert ticket, seating number, E-ticketing
\end{abstract}

\section{PENDAHULUAN}

Di masa sekarang ini perkembangan teknologi sangatlah cepat, perkembangan teknologi informasi kini telah mengubah aspek aspek kehidupan tradisional masyarakat kearah digital, sehingga dapat mempermudah masyarakat dalam berbagai hal. Komputer merupakan alat bantu manusia dalam melakukan pekerjaannya adalah salah satu hasil dari kemajuan teknologi, selain komputer ada juga internet yang berfungsi sebagai jaringan penghubung antara komputerkomputer diseluruh dunia. Munculnya jaringan Internet telah mengubah pola hidup masyarakat dalam berbagai bidang seperti social, ekonomi, budaya.

Industri musik saat ini juga sedang ramai ramainya, pertunjukan konser pun sangat banyak 
dilakukan oleh musisi musisi baik artis dalam negeri maupun luar negeri. Pihak penyelenggara atau EO, sudah menjadi rahasia umum bila rilisan fisik - yang dulunya merupakan sektor paling menghasilkan dalam industri musik terus mengalami kerugian akibat pembajakan yang terjadi dimana-mana, ditambah lagi dengan maraknya layanan streaming . Satu-satunya pemasukan utama yang bisa diharapkan para musisi adalah melalui panggung-panggung mereka. Mari kita sama-sama amati statistik berikut ini. Sejak tahun 1999 hingga tahun 2014, penjualan rilisan fisik turun drastis hingga 44 persen sementara itu konser musik, yang pendapatan utamanya berasal dari tiket penjualan, terus meraih keuntungan.

Konser musik diperkirakan akan terus berkembang pesat. Sebuah jaringan lembaga profesional asal Inggris, PricewaterhouseCoopers, memprediksi bahwa sektor ini akan meraup keuntungan sebesar \$30,9 miliar (sekitar Rp428,82 triliun) pada tahun 2019, angka tersebut naik dari \$26 miliar (sekitar Rp360,88 triliun) pada tahun 2014.

Lalu, apa dampak dari fenomena ini? Dulu, para artis dan musisi melakukan tur, tampil di berbagai konser dan festival, untuk memperkenalkan album dan lagu terbaru mereka sebagai bentuk promosi yang bisa mendorong penjualan rekaman fisik mereka. Namun, akibat semakin mudahnya akses internet, berbagi file secara online, dan kehadiran streaming musik , berimbas pada menurunnya penjualan rilisan fisik mereka, sehingga industri musik dipaksa untuk mengubah model pendapatan mereka.

Dari pemikiran diatas, maka tentu saja akan membuat dampak yang besar bagi perusahaan Event Organizer yang sekaligus menjadi penjual tiket terutama tiket konser musik. Terlepas dari pertumbuhan industri yang fenomenal ini dan makin banyaknya konser musik, pihak manajemen dan penjual tiket nya masih menganut cara konvensional, maksudnya, hampir segala hal diatur dan dijalankan secara manual, mulai dari penjualan tiket, sampai pemilihan tempat duduk dalam gedung atau area konser.

Di sinilah peran penelitian ini diperlukan. Sebagai permulaan, peneliti akan merancang sebuah program untuk penjualan tiket online yang bisa langsung untuk memilih tempat duduk sehingga customer akan bisa langsung memilih kursi yang akan mereka tempati pada acara konser nanti, keluaran dari hasil transaksi tersebut adalah E-ticketing dengan barcode yang bisa disimpan menggunakan smartphone atau bisa juga di print yang nantinya akan di pindai barcode dengan menggunakan aplikasi check-in oleh staf acara yang bertugas di gerbang masuk dalam waktu yang singkat, karena sudah tidak perlu lagi untuk memilih kursi yang tersedia pada saat hari-H, dan hasilnya, antrian semakin pendek dan pengunjung dapat segera masuk.

Pada penelitian ini terkemuka beberapa permasalahan penelitian antara lain: Pembeli tiket merasa kesulitan, karena tiket yang sudah dibeli harus ditukar di hari-H dengan tiket fisik dan harus memilih kursi di hari-H, sehingga jika mereka datang tidak diawal-awal penukaran maka kursi yang akan di tempati sudah ditempati oleh pembeli lainnya. Pihak penyelenggarapun akan merasa kesulitan pada hari-H karena akan melayani pemilihan kursi yang sangat banyak. iscepisehubungan dengan hal tersebut diatas maka penulis mencoba untuk merumuskan masalah sebagai berikut: Bagaimana membuat perancangan Sistem Informasi Penjualan Tiket Konser Berbasis Web?

Adapun tujuan penulisan ini adalah untuk merancang sistem informasi penjualan tiket konser musik dengan seating number berbasis web yang nantinya akan digunakan untuk menjual tiket konser musik secara online dengan pemilihan kursi, sehingga bisa mengatasi masalah yang telah dituliskan diatas. Dalam penyusunan penelitian ini penulis menggunakan beberapa metode pengumpulan data yaitu: wawancara, studi lapangan, studi pustaka serta membuat prototype yang bisa langsung digunakan untuk kepentingan penelitian.

\section{TINJAUAN PUSTAKA}

Berdasarkan pada penelitian sebelumnya yaitu Perancangan Informasi Penjualan Konser Musik Pada PT Insan Karya Aruna Nusa (Motikdong.com) yang ditulis oleh Wahyudi, M.Kom. (Wahyudi, 2019), dimana penjualan tiket yang dilakukan masih mengalami masalah yaitu terjadinya kesulitan pada saat penukaran 
tiket fisik di hari $\mathrm{H}$, karena semua konsumen menukarkan E-ticketing dengan tiket fisik dihari yang bersamaan. Oleh karena itu pada penelitian sekarang ditambahkan fitur pada sistem yaitu pemilihan seating number, yang bisa memilih kursi pada saat pemesanan tiket dilakukan. Metode pengembangan aplikasi yang digunakan adalah metode pengembangan prototype yaitu metode yang menggunakan pendekatan untuk membangun suatu program dengan cepat dan bertahap sehingga segera dapat dievaluasi oleh pemakai, dengan tahapan yang digunakan yaitu pengumpulan kebutuhan dan perbaikan, perancangan cepat, membentuk prototype, evaluasi pelanggan terhadap prototype, Perbaikan prototype dan produk rekayasa.

Pengertian Sistem informasi menurut Kadir (Kadir, 2014) adalah "sebuah rangkaian prosedur formal dimana data dikelompokkan, diproses menjadi informasi, dan didistribusikan kepada pemakai". Pengertian Sistem informasi menurut Krismaji (Krismiaji, 2015) Sistem informasi adalah cara-cara yang diorganisasi untuk mengumpulkan, memasukkan, dan mengolah serta menyimpan data, dan cara-cara yang dior- ganisasi untuk menyimpan, mengelola, me- ngendalikan, dan melaporkan informasi sede- mikian rupa sehingga sebuah organisasi dapat mencapai tujuan yang telah ditetapkan.

Laudon (Laudon, Kenneth C \& Laudon, 2014) juga mendefinisikan sistem informasi: Secara teknis sebagai sesuatu rangkaian yang komponen-komponennya saling terkait yang mengumpulkan (dan mengambil kembali), memproses, menyimpan dan mendistribusikan informasi untuk mendukung pengambilan keputusan dan mengendalikan perusahaan.

Jadi berdasarkan pengertian diatas dapat disimpulkan bahwa sistem informasi adalah kumpulan data yang terintegritasi dan saling melengkapi dengan menghasilkan output yang baik guna untuk memecahkan masalah dan pengambilan keputusan.

\section{METODE PENELITIAN}

Pada bab ini akan dijelaskan solusi yang ditawarkan untuk mengatasi permasalahan yang diangkat oleh penelitian ini yaitu pemberian nomor kursi pada setiap event konser musik.
Pada penelitian ini penulis menggunakan metode prototype yang dirasa tepat untuk penambahan fitur dalam hal ini seating number dalam pengembangan sebuah sistem yang sudah berjalan sebelumnya yang didalamnya meliputi pengumpulan kebutuhan, perancangan cepat, membentuk prototype, evaluasi pelanggan, perbaikan prototype, rekayasa produk. Tahapan pengumpulan kebutuhan dan perbaikan merupakan proses melakukan pengumpulan bahan atau data yang sesuai dengan penelitian yang akan dikembangkan. Dalam proses pengumpulan kebutuhan data dilakukan studi literatur terhadap aplikasi yang serupa pada penelitian sebelumnya yang bertujuan untuk mengetahui apakah aplikasi yang serupa tersebut dapat dikembangkan atau tidak.

Tahapan Perancangan cepat merupakan tahapan proses untuk menghubungkan antara kebutuhan yang sebelumnya telah dilakukan menggunakan studi literatur terhadap aplikasi dengan tema yang sama yang diterjemahkan ke dalam diagram-diagram UML (Unified Modeling Language) (Munawar, 2005) diantaranya dalam bentuk use case diagram, activity diagram, dan sequence diagram, membuat perancangan antarmuka tampilan aplikasi yang dilanjutkan pada tahapan membentuk prototype dimana mencakup tahapan instalasi perangkat lunak pendukung, pembuatan aplikasi, beserta pengujian black box (Al Fatta, 2007).

Tahapan bentuk prototype merupakan tahapan dimana file-file atau data-data hasil dari tahapan pengumpulan kebutuhan perbaikan digabungkan menggunakan perangkat lunak pendukung yang mana hasilnya menjadi source code program beserta aplikasi berbentuk website.

Tahapan evaluasi pelanggan terhadap prototype merupakan tahapan pengujian aplikasi yang sebelumnya dihasilkan dalam tahapan bentuk prototype yang dilakukan oleh pengguna dengan mengakses website tersebut dan melakukan pembelian. Tahapan ini dilakukan dengan melakukan pengujian dan pengisian lembar kuesioner evaluasi kepada pengguna.

Tahapan perbaikan prototype merupakan tahapan dimana dilakukan perbaikan kesalahan atau kelemahan-kelemahan yang terdapat pada 
aplikasi yang telah dibangun. Tahapan perbaikan prototype dilakukan berdasarkan hasil pengujian yang telah dilakukan sebelumnya oleh pengembang dan responden.

Tahapan produk rekayasa merupakan tahapan dimana produk yang sudah jadi dan siap digunakan oleh pengguna.

\section{HASIL DAN PEMBAHASAN}

Dalam tahap pengumpulan kebutuhan maka penulis mencoba mengumpulkan beberapa informasi dari hasil wawancara dan studi literature serta langsung mencoba menggunakan sistem berjalan dan memahami skenario yang ada.

Tahap perancangan cepat ini bertujuan untuk menghubungkan antara kebutuhan pengguna, baik konsumen ataupun admin serta petugas yang ada dilapangan nantinya. Pada tahap ini dibuatlah diagram-diagram interaksi dengan pemodelan UML. Diagram ini dibuat berdasarkan aktor pengguna sistem yang meliputi use case, activity diagram dan sequence diagram. Dengan dilakukannya perancangan ini diharapkan mampu meminimalisasikan kesalahan pada rancangan pengembangan program yang akan dibuat sampai ketahap implementasi nantinya.

Usecase diagram adalah diagram usecase yang digunakan untuk menggambarkan secara ringkas siapa yang menggunakan sistem dan apa saja yang bisa dilakukannya. Diagram use case tidak menjelaskan secara detail tentang penggunaan usecase, namun hanya memberi gambaran singkat hubungan antara usecase, aktor, dan sistem. Use case pada penelitian ini menggambarkan tentang aktor konsumen dan admin.

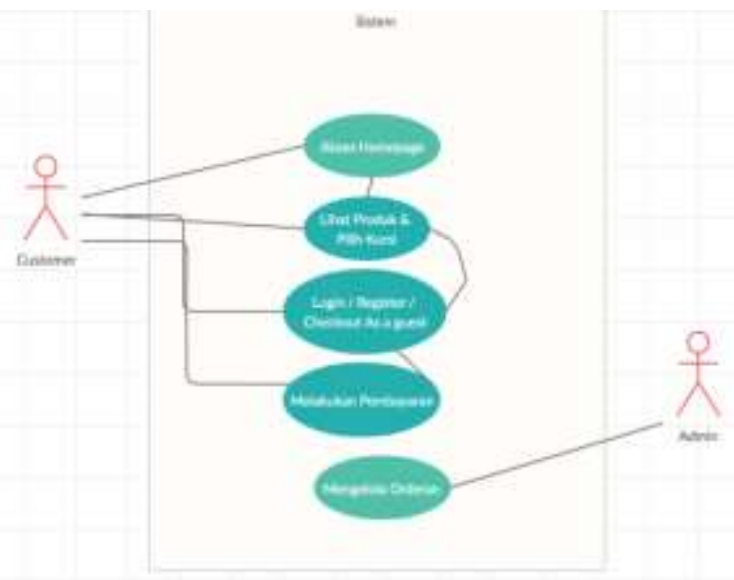

Sumber: (Wahyudi 2020)

Gambar 1. Use Case Website Motikdong.com

Activity Diagram dibuat setelah pembuatan use case, dengan cara memodelkan secara grafis dari langkah-langkah setiap aktifitas yang dilakukan kedalam sebuah activity diagram.

Sequence Diagram dibuat setelah use case dan activity diagram dibuat untuk menggambarkan interaksi antar object dimana contoh disini adalah interaksi antara aktor dengan sistem melalui pesan yang dikirimkan dari object $1 \mathrm{ke}$ object yang lain.

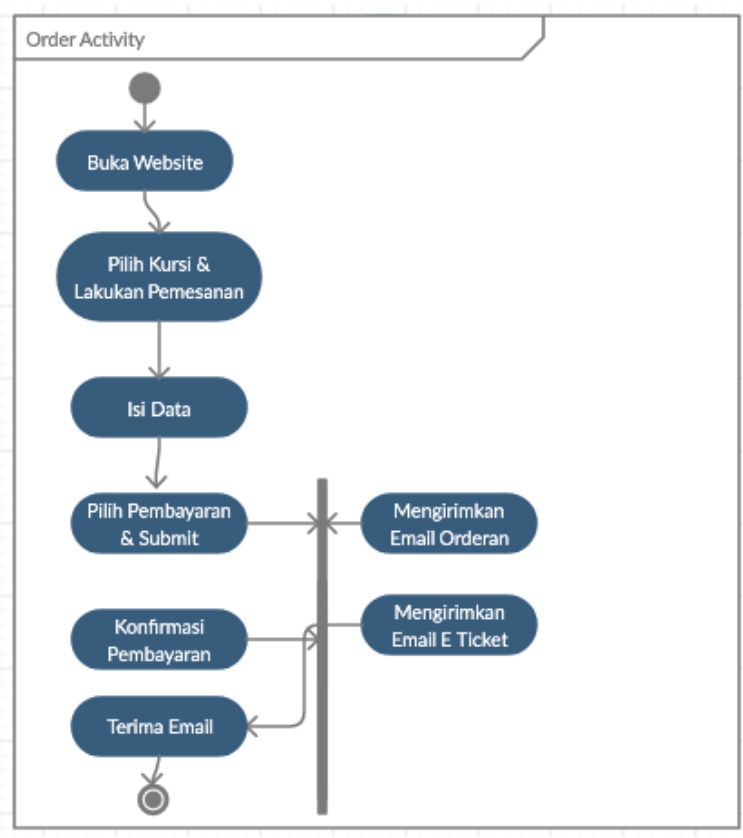

Sumber: (Wahyudi 2020)

Gambar 2. Activity Diagram Website Motikdong.com 
Berdasarkan rancangan UML diatas maka langkah selanjutnya adalah membuat rancangan antarmuka yang sesuai

Halaman Utama

Untuk antar muka pengguna terdiri dari halaman utama, dimana ada banner slider utama, serta tiket tiket yang dijual seperti gambar dibawah ini,

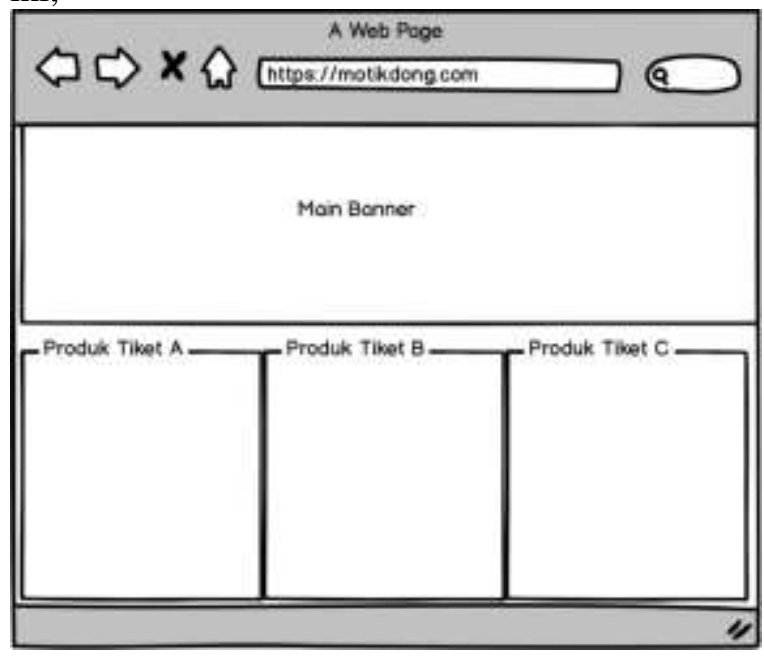

Sumber: (Wahyudi 2020)

Gambar 3. Rancangan Halaman Utama Website motikdong.com

Halaman Detail Konser

Pada halaman ini memberikan detail informasi tiket konser yang dijual, termasuk layout kursi dan panggung didalamnya.

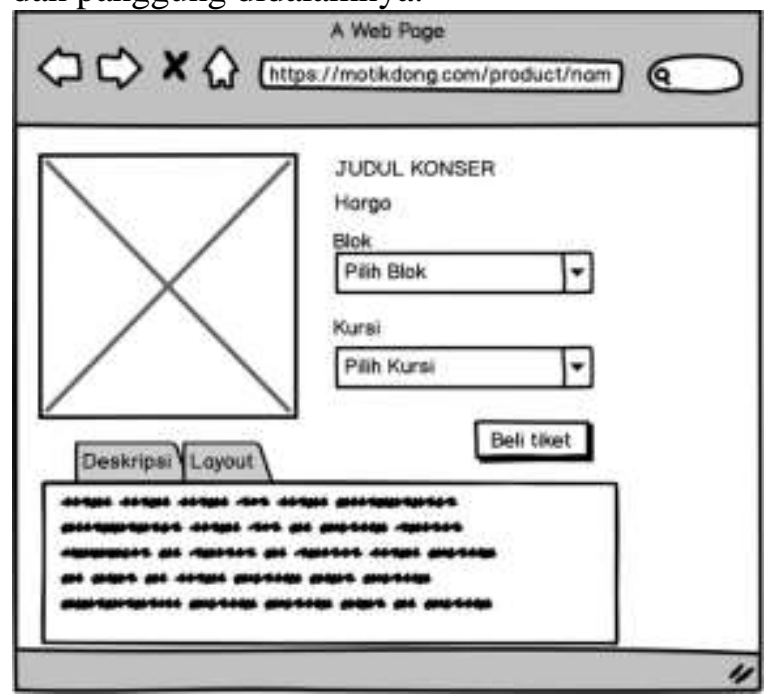

Sumber: (Wahyudi 2020)

Gambar 4. Rancangan Halaman Detail Konser Website motikdong.com
Halaman Keranjang Belanja

Pada halaman ini calon pembeli bisa melihat tiket konser apa saja yang mereka sudah pilih untuk dibeli, serta mereka bisa melihat berapa total yang harus dibayarkan. Pada halaman ini ada 2 button yaitu lanjutkan belanja dimana akan di redirect ke halaman konser yg dijual, serta button lanjutkan pembayaran yang akan meredirect ke halaman pembayaran.

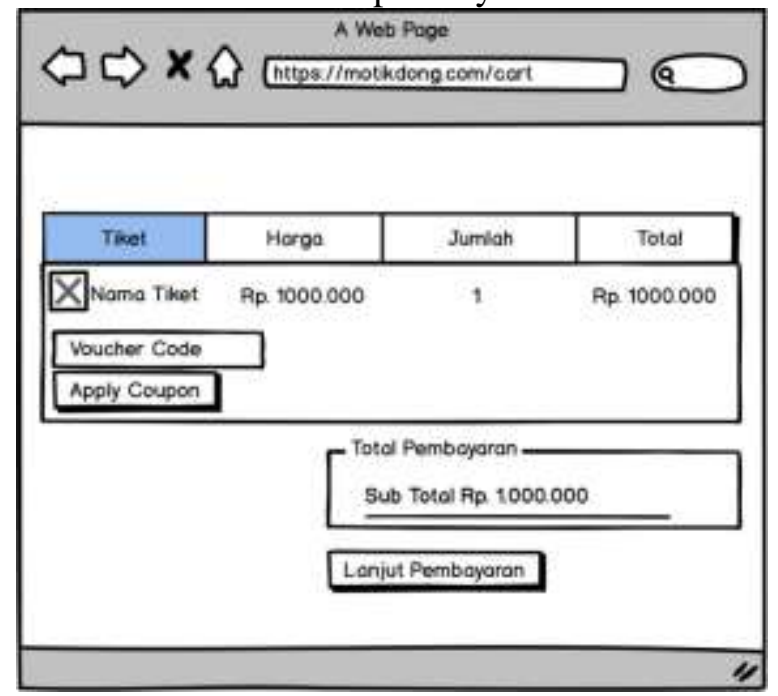

Sumber: (Wahyudi 2020)

Gambar 5. Rancangan Halaman Keranjang

Belanja Website motikdong.com

Halaman Pembayaran

Pada Halaman ini calon pembeli diminta untuk mengisi nama, alamat, email serta nomor handphone untuk melengkapi pembelian tiket, serta memilih metode pembayaran, dimana pembayaran dengan metode transfer bank akan langsung dilarikan ke halaman terima kasih, dan jika calon pembeli memilih pembayaran dengan credit card maka akan dialihkan ke halaman payment gateway dan jika berhasil membayar akan menampilkan halaman terima kasih, namun jika tidak maka akan menampilkan halaman gagal bayar. 


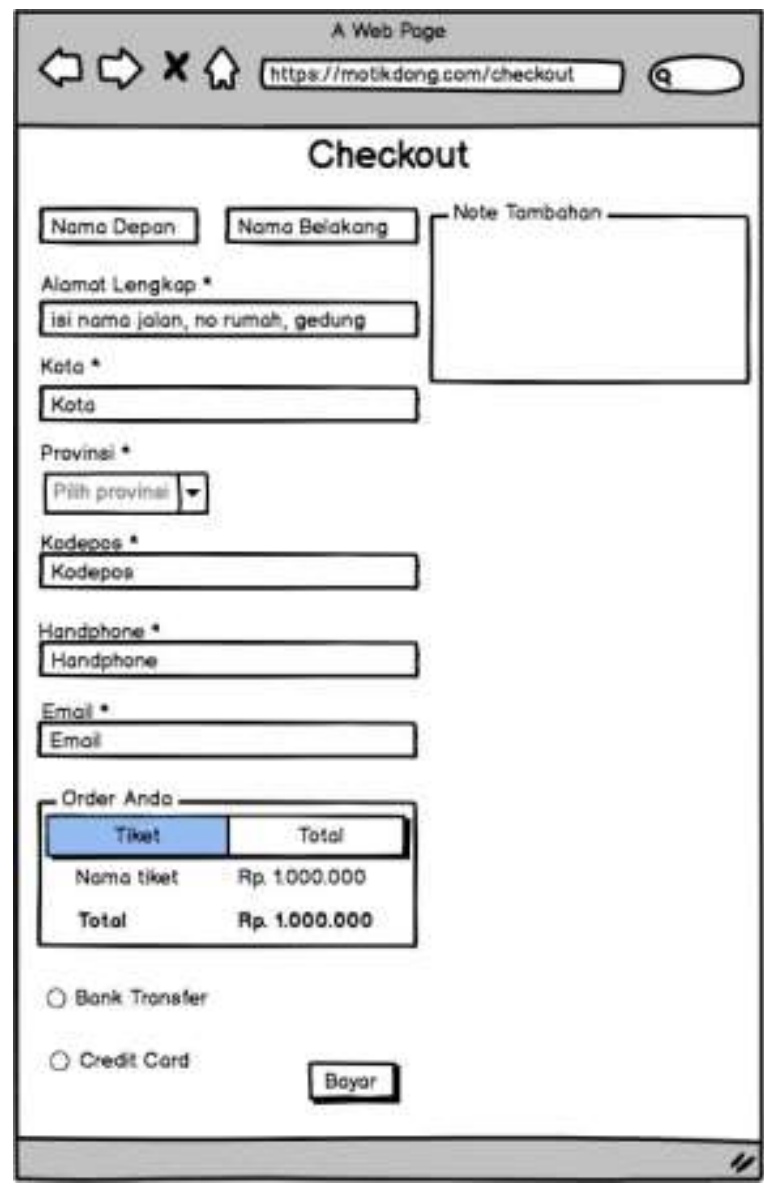

Sumber: (Wahyudi 2020)

Gambar 6. Rancangan Halaman Pembayaran

Website motikdong.com

\section{Implementasi}

Berdasarkan proses analisa dan perancangan serta pembuatan diagram dan pengembangan dari pembuatan mockup maka berikut tampilan hasil dari sistem yang dibangun.

Halaman utama merupakan halaman untuk menampilkan sesuatu yang sangat penting yaitu slider yang menampilkan poster event konser yang sedang berlangsung dan langsung diberikan link untuk membeli tiket konser tersebut. Halaman ini juga menampilkan, contact us. Tampilan interface sistem dapat dilihat pada Gambar 7 sampai Gambar 11.
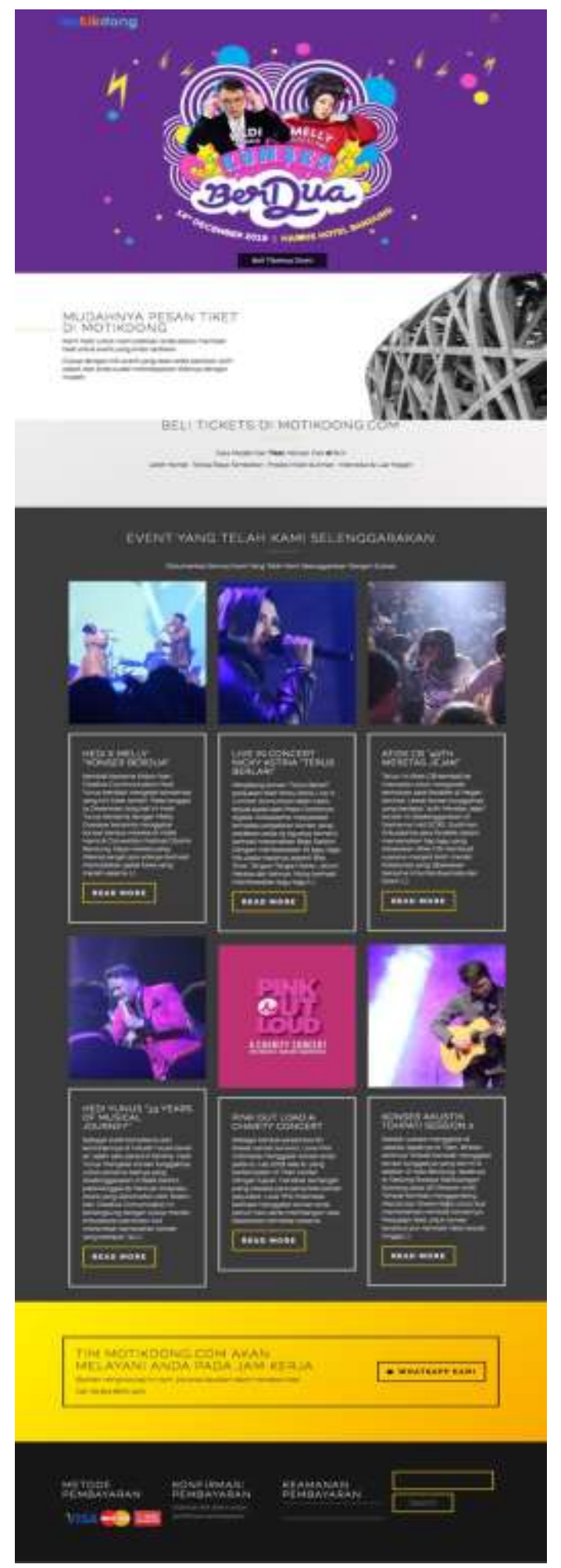

Sumber: (Wahyudi 2020)

Gambar 7. Tampilan utama sistem Website Motikdong 


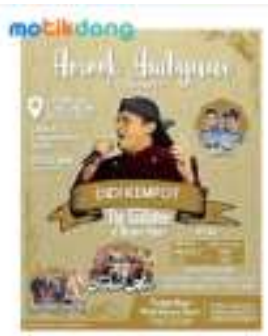

DIDI KEMPOT - AMBYAR 30 TAHUN BERKARYA

Rp 1000.000

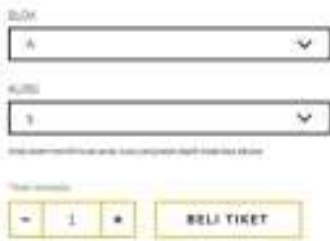

Sumber: (Wahyudi 2020)

Gambar 8. Halaman Detil Produk Website Motikdong.com

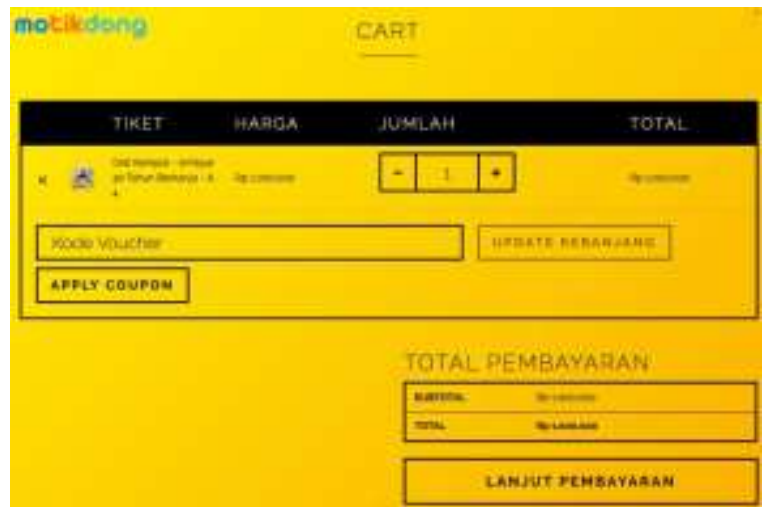

Sumber: (Wahyudi 2020)

Gambar 9. Halaman Keranjang Belanja Website Motikdong.com

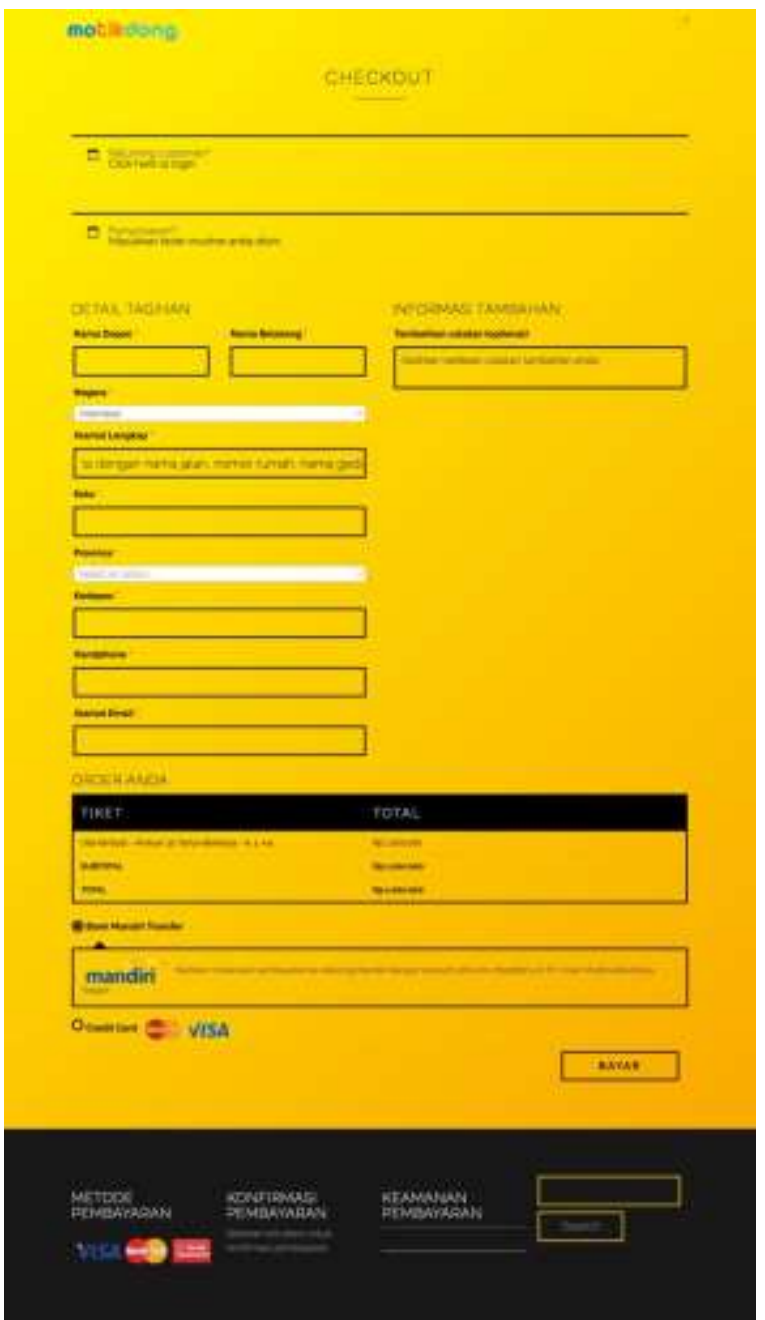

Sumber: (Wahyudi 2020)

Gambar 10. Halaman Isi Data \& Pembayaran Website Motikdong.com

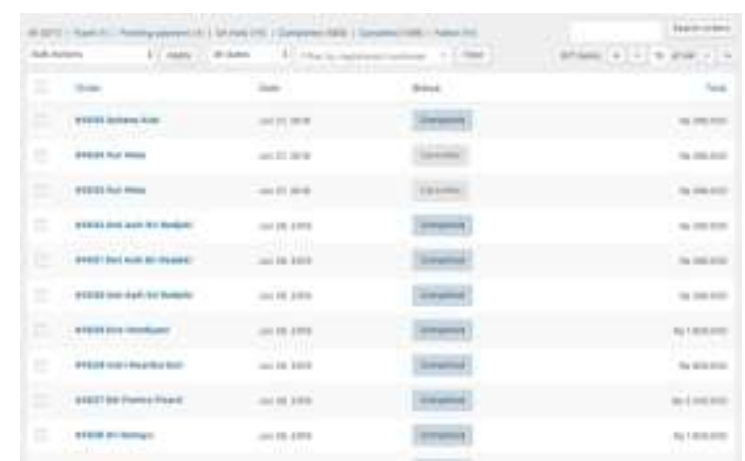

Sumber: (Wahyudi 2020)

Gambar 11. Halaman Order Admin Website Motikdong.com 


\section{KESIMPULAN}

Pengembangan Aplikasi Sistem E-Ticketing Konser Musik Dengan Seating Number sebagai pengembagan Informasi penjualan tiket konser musik berbasis web yang telah dibuat sebelumnya merupakan suatu aplikasi yang dibuat guna mempermudah proses penjualan tiket pada PT Insan Karya Aruna Nusa (Kolam Ikan) sekaligus memberikan solusi atas permasalahan yang telah dijelaskan diatas. Aplikasi ini dibuat dengan terlebih dahulu dilakukan penganalisisan sistem lama, penganalisisan kebutuhan pengguna, penganalisisan kelayakan sistem, perancangan desain sistem yang meliputi pemodelan proses dengan UML sebagai alat bantu desain, pemodelan data dengan membuat rancangan tabel, dan perancangan antarmuka (design interface) yang disesuaikan dengan keinginan. Sistem ini telah di uji coba kan langsung pada website motikdong.com dan pada akhirnya pengembangan sistem ini berhasil mengatasi permasalahan tentang tempat duduk penonton dan berhasil mengurangi antrian dalam penukaran tiket di hari-H

Penulis mengembangkan aplikasi ini dengan Bahasa pemrograman PHP dengan database MySQL. Aplikasi web ini bersifat user friendly sehingga pengguna dapat dengan mudah menjalankan aplikasi ini dalam hal order baik dari sisi pelanggan maupun admin. Aplikasi web ini bersifat sederhana, bahasa yang digunakan mudah dimengerti, sehingga tidak memerlukan waktu yang lama untuk pelatihan menggunakan aplikasi web ini.

\section{REFRENSI}

Kadir, A. (2014) Pengenalan Sistem Informasi Edisi Revisi. Yogyakarta: Andi.

Krismiaji (2015) Sistem Informasi Akuntansi. Yogyakarta: Unit Penerbit.

Laudon, Kenneth C \& Laudon, J. P. (2014) 'Sistem Informasi Manajemen: Mengelola Perusahaan Digital Edisi 13', in. Jakarta: Penerbit Salemba Empat.

Wahyudi (2019) 'Perancangan sistem informasi penjualan tiket konser music pada pt.insan karya aruna nusa', Journal of Chemical Information and Modeling, 4(9), pp. 11-20. doi: 10.1017/CBO9781107415324.004. 